\title{
Effects of Packaging Materials and Seed Treatments Chemicals on Seed Quality Attribute in Vegetable Soybean during Storage
}

\author{
K. Nataraj* and Jayaramegowda \\ AICRP on Soybean, UAS, GKVK, Bengaluru-560 065, India \\ *Corresponding author:
}

\section{A B S T R A C T}

\begin{tabular}{|l|}
\hline Ke y w o r d s \\
Vegetable \\
soybean, \\
Trypsin inhibitor, \\
Seed quality.
\end{tabular}

An experiment was conducted at AICRP on Soybean, ZARS, University of University of Agricultural Sciences, Bengaluru during 2015-16. The main objective is to study the effect of storage packages (Tin, polythene bag 700 gauge and cloth bag) on seed quality on vegetable soybean var. Karune. Seeds were stored in room temperature for nine months. The observation were recorded at trimonthly interval on seed quality parameter and the result indicated that higher seed germination $(73.11 \%)$ were noticed seed stored in tin fallowed by seeds stored in polythene bag $\left(\mathrm{P}_{2}\right)$, seed germination $(71.78 \%)$ stored in polythene bag and lower seed quality was noticed in cloth bag $\left(\mathrm{P}_{3}\right)$ (germination $(68.30 \%)$ at the end of the storage period. Hence, the study indicated that, vegetable soybean variety Karune seed could be treated with bavisitin @ 3g per kg of seed and stored in tin container without affecting seed germination up to nine months.

\section{Introduction}

Soybean [Glycine max (L.) Merrill] is one of the largest protein rich grain crop in the world. Notwithstanding that its grain has $40 \%$ protein and $18-19 \%$ oil, nutritionally, it is considered inferior for human consumption as it contains protease trypsin inhibitor, which is anti-nutritional. On the other hand, freshly harvested tender green pods ( $80 \%$ maturity) are good as vegetable like green peas and lima beans these are called vegetable types. Seeds of vegetable types are bolder and immature green seeds are highly nutritious with distinct flavor. Fresh green seeds can be cooked instantaneously and or frozen or canned for later use. They are rich in most of the essential nutrients and are devoid of anti- nutritional factors. Seed germination is the resumption of active growth of the embryo that results in the rupture of the seed coat and the emergence of the young plant (Tame, 2011). Seed quality is affected during pre and post-harvest period (Walters et al., 2005). Soybean seed reaches its maximum potential for germination and vigour at physiological maturity. The germination potential is very short lived in soybean as compared to other oilseed crops and is often reduced prior to planting time, Agha et al., (2004). This loss of germination is much more acute under tropical conditions Tatipata (2009). These environmental conditions make maintenance of soybean seed viability during storage very 
difficult. One of the major constraints in Soybean cultivation is the non-availability of high vigour seeds at the time of sowing. Rising demand for oil and protein has stimulated soybean production mainly by increasing land use. Poor seed germination is a major constraint for increasing the productivity of Soybean. Seed longevity is greatly influenced by the relative humidity a storage- temperature. The decline of seed germination is much more acute under tropical conditions. These environmental conditions make very difficult to maintain its viability during storage. Shelar et al., (2008),Good storage is a basic requirement in seed production programme as the maintenance of high seed viability and vigour from the harvest to planting is of utmost important in a seed production programme. In storage, the seed are to be protected against the pests and pathogens. The seeds can be treated with different fungicides to prevent the growth of microorganisms and insect infestation. Seed treatments with fungicides not only controls seed born diseases but also improves seed health, plant stand, seed germination and crop yield. Fungicide treatments are required for to be stored for several months and stability of fungicides affects without affecting the seed health adversely. Off late, attempts have been made to replace synthetic (inorganic) seed treatment chemicals with organic materials of plant origin which are cheaper, safer and ecofriendly Parashivamurthy (1994). Among the various methods followed, use of botanicals has been a traditional method and is being given much attention particularly in the Indian context where the farmers have a rich heritage of Indigenous Technical Knowledge (ITK) inherited from their ancestors. Keeping in view these facts, the aim of the study was to determine the effects of different seed treatment chemicals and packing materials on seed germination. This study aims at investigating various chemical treatments and storage materials that could ensure good quality of seeds of soybean crop.

\section{Materials and Methods}

Seeds of vegetable soybean variety Karune were cleaned, dried with safer moisture level and treated with bavistin $\left(\mathrm{C}_{1}\right)-3 \mathrm{~g} / \mathrm{kg}$ seed $)$, Thairam $\left(\mathrm{C}_{2}\right)-4 \mathrm{~g} / \mathrm{kg}$ seed $)$ and Control $\left(\mathrm{C}_{3}\right)$. The treated seed were packed in different packing materials viz., Tin $\left(\mathrm{P}_{1}\right)$, Polythene bag 700 gauge $\left(\mathrm{P}_{2}\right)$ and Cloth bag $\left(\mathrm{P}_{3}\right)$ and stored for nine months storage period under room temperature at AICRP on Soybean, UAS, Bengaluru. Observation on seed germination was taken at an interval of three months and treated seeds are put for germination test, the germination was conducted in laboratory using between paper methods as per ISTA (Anon., 1996). Hundred seeds of three replicates were placed equidistantly between moist Kraft paper towels. The rolled towels were placed in the germination chamber, where $25 \pm 1{ }^{0} \mathrm{C}$ and 90 per cent $\mathrm{RH}$ was maintained. The seedling was evaluated on $8^{\text {th }}$ day of incubation and the cumulative percentage of germination was expressed based on normal seedling. The data obtained from the experiment was statistically analysed by using factorial CRD, the critical differences between the treatments were worked out at five per cent significance (Snedecor and Corchran, 1967).

\section{Results and Discussion}

Seed deterioration is an irreversible and inexorable process, which cannot be prevented during storage. However, the process can be slowed down. Various factors such as sensitivity of seed to environment, multiplicity of varieties, seasonal demand, specific planting time, disposal at end use areas, necessity to carryover seeds, need for buffer seed stocks make seed storage an imperative and inescapable proposition. 
Physiological quality of the seed is highest when it completes 'structural' and 'functional' development on the plant itself. Thereafter, it deteriorates 'irrepairably and irreversibly' at varying rates. This rapid deterioration of stored seeds is a serious problem, particularly in India where high temperature and high relative humidity prevail and associate to accelerate the seed ageing phenomena. The control of temperature and humidity during storage has a profound influence on the 'vigour' and 'viability' potential of seeds. Changes which occur during storage and are associated with deterioration such as delayed germination, reduced seedling growth rates, decreased tolerance to adverse germination conditions and loss of germinability (Abdul-Baki and Anderson, 1972) are some of the 'physiological manifestations' of seed deterioration. Presumably, these changes are associated with shifts in metabolism. Biochemical measurements that have been tested for correlations with germinability, vigour, changes in seed constituents, nature and level of enzymatic activity and metabolic processes during the early hours of germination. Each had been used with various successes in many crop plant species to gain knowledge about deterioration process.

However, they are of little relevance to Indian conditions to any crop in general and soybean in particular. Moreover, the available information on the pattern of seed deterioration in relation to loss of germinability and seedling vigour and the cheap means of seed treatments to protect sunflower in storage is very scanty. The present study is an attempt to gather information on the nature of seed germination, effect of packaging materials and seed treatment chemicals for the retention of seed viability during storage under ambient conditions. The longevity of seeds in storage is influenced by four major factors viz., i) Genetics, ii) Quality of the seed at the time of storage, iii) Moisture content of seed or ambient RH, iv) Temperature of storage environment. The effects of the packaging materials, chemicals and their interaction on germination percentage of soybean seeds stored for nine months are presented in table 1.

Significant differences between packaging materials throughout storage period expect third month of storage period. Among the packaging materials, seed stored in Tin $\left(\mathrm{P}_{1}\right)$ was recorded maximum seed germination $(73.11 \%)$ fallowed by polythene bag $\left(\mathrm{P}_{2}\right)$ $(71.78 \%)$ similar results reported by Tame and Elam, (2015) and lower seed germination were recorded in cloth $\operatorname{bag}\left(\mathrm{P}_{3}\right)(68.30 \%)$ decline in germination percentage with advance in storage period. Similarly, may be attributed to aging effect, leading to depletion of food reserves and decline in synthetic activity of embryo apart from loss of viability and storage condition and might be development of storage fungi which resulted in poor performance in seed stored in cloth bag. Tekrony et al., (1993)

Seed treatment showed significant influence on germination percentage. Germination was maximum with bavistin $\left(\mathrm{C}_{1}\right)(73.89 \%)$ treated seeds followed by seeds treated with Thairam $\left(\mathrm{C}_{2}\right) \quad(71.89 \%)$. The minimum seed germination was recorded $(67.44 \%)$ with control $\left(\mathrm{C}_{3}\right)$ seeds at the end of nine month storage. These result accorded with Sushma (2003). The interaction effect of containers and chemicals showed significant differences throughout storage period except zero and third month of storage. The seed treated with bavistin and stored in tin recorded maximum seed germination $\mathrm{P}_{1} \mathrm{C}_{1}(75.30 \%)$ fallowed by stored in polythene bag $\mathrm{P}_{2} \mathrm{C}_{1}(74.00 \%)$ at the end of storage period. Similar result reported by Kandil et al., (2013). 
Table.1 Effect of storage package and seed treatment chemicals on seed germination per cent during storage vegetable soybean var. Karune

\begin{tabular}{|c|c|c|c|c|}
\hline \multirow{2}{*}{ Treatments } & \multicolumn{4}{|c|}{ Storage periods (Months) } \\
\hline & $\mathbf{0}$ & 3 & 6 & 9 \\
\hline \multicolumn{5}{|c|}{ Packaging } \\
\hline $\mathrm{P}_{1}$ & 97.33 & 92.67 & 82.11 & 73.11 \\
\hline $\mathrm{P}_{2}$ & 95.33 & 91.44 & 80.56 & 71.78 \\
\hline $\mathrm{P}_{3}$ & 95.56 & 91.00 & 78.22 & 68.33 \\
\hline S.Em \pm & 0.83 & 0.80 & 0.41 & 0.68 \\
\hline CD (0.05P) & 2.46 & NS & 1.21 & 2.04 \\
\hline \multicolumn{5}{|c|}{ Chemicals } \\
\hline $\mathrm{C}_{1}$ & 96.56 & 93.56 & 81.44 & 73.89 \\
\hline $\mathrm{C}_{2}$ & 95.67 & 91.78 & 80.78 & 71.89 \\
\hline $\mathrm{C}_{3}$ & 96.00 & 89.78 & 78.67 & 67.44 \\
\hline S. Em \pm & 0.83 & 0.80 & 0.41 & 0.68 \\
\hline CD (0.05P) & 2.46 & 2.37 & 1.21 & 2.04 \\
\hline \multicolumn{5}{|c|}{ Interaction ( P x C) } \\
\hline $\mathrm{P}_{1} \mathrm{C}_{1}$ & 98.0 & 95.7 & 84.7 & 75.3 \\
\hline $\mathrm{P}_{1} \mathrm{C}_{2}$ & 97.7 & 92.7 & 82.7 & 73.3 \\
\hline $\mathrm{P}_{1} \mathrm{C}_{3}$ & 96.3 & 89.7 & 79.0 & 70.7 \\
\hline $\mathrm{P}_{2} \mathrm{C}_{1}$ & 95.0 & 93.3 & 80.7 & 74.0 \\
\hline $\mathrm{P}_{2} \mathrm{C}_{2}$ & 95.7 & 92.7 & 81.3 & 71.3 \\
\hline $\mathrm{P}_{2} \mathrm{C}_{3}$ & 95.3 & 88.3 & 79.7 & 70.0 \\
\hline $\mathrm{P}_{3} \mathrm{C}_{1}$ & 96.7 & 91.7 & 79.0 & 69.10 \\
\hline $\mathrm{P}_{3} \mathrm{C}_{2}$ & 93.7 & 90.0 & 78.3 & 71.0 \\
\hline $\mathrm{P}_{3} \mathrm{C}_{3}$ & 96.3 & 91.3 & 77.3 & 61.7 \\
\hline S.Em \pm & 1.43 & 1.38 & 0.70 & 1.19 \\
\hline CD (0.05P) & NS & NS & 1.79 & 3.02 \\
\hline $\mathrm{CV}(\%)$ & 2.58 & 2.61 & 1.52 & 2.89 \\
\hline
\end{tabular}

\section{Packaging:}

$\mathbf{P}_{1}$ : Tin

$\mathbf{P}_{2}$ : Polythene bag

$\mathbf{P}_{3}$ : Cloth Bag

\section{Chemicals:}

$\mathbf{C}_{1}$ : Bavistin @ 3g/kg seed

$\mathbf{C}_{2}$ : Thairam @ 4g/kg seed

$\mathbf{C}_{3}$ : Control
The variation in germination percentage of soybean seed decreased with increase storage period which might be due to the deleterious effects of moisture which resulted from the storage materials and perhaps environmental conditions. This agrees with Tame (2011) who reported that germination percentage of onion seed decreased with increase in storage period. Might be effective control of storage disease, insect and pest, whereas the chemicals acts as antioxidants to counteract the release of free radicals during storage The lower seed germination were recorded in cloth bag with control $\mathrm{P}_{3} \mathrm{C}_{3}(61.70 \%)$ at end of the storage period. These results were supported by Jaya Joshi (2014) and these were below minimum seed standards $(70 \%)$. However, result reported by Sajo and Tame (2012) that storage of soybean seed in poly bags preserved viability and reduced invasion 
by storage fungi compared with jute or cloth bags. It was further reported by Tame et al., (2013) that poly bag storage was the most efficient method of vegetable soybean seeds to maintain quality. Also, Mettananda et al., (2001) concluded that seeds stored in poly bags were superior in storability in maintaining the vigor. Similarly, Pessu et al., (2006) reported that polythene bag and metal tin were better storage containers than the bamboo bin and clay pot.

The study indicated that, vegetable soybean variety Karune seed could be treated with Bavisitin@3g per kg of seed and stored in tin container without affecting seed germination up to nine months.

\section{References}

Abdul-Baki, A.A. and Anderson, J.D. 1972. Vigour determination in soybean and multiple criteria. Crop Sci., 13: 630663.

Anonymous. 1996. International Rules for Seed Testing (ISTA. Seed Sci. \& Technol., 24 (Supplement Rules).

Jaya Joshi, Azad Ahmad Wani, Anurag Titov and D.S. Tomar. 2014. Seed Quality Parameters of Soybean (Glycine Max. L.) As Influenced by Seed Treating Fungicides and Botanicals and Packing Materials. Indian J. Res., 3(4): 219-222.

Kandil, A.A., Sharief A.E., Sheteiwy M.S. 2013. Effect of seed storage periods, Conditions and Materials on Germination of some Soybean seed cultivars. American J. Exp. Agri., 3(4): 1020-1043.

Menttananda, K.A., Weerasena, S.L. and Liyanage, Y. 2001. Effect of storage environment, packing material and seed moisture content on storability of maize (Zea mays L.) seeds. Annals of the Department of Agri., 3: 131-142.
Parashivamurthy, K.M. 1994. Role of chemical seed treatment on seed quality and longevity of soybean. M.Sc. Agri.. Thesis. University of Agricultural Sciences, Bangalore. pp. 59.

Pessu, P.O., Adindu, M.N. and Umeozor, O.C. 2006. Effects of long-term storage on the quality of soybean, Glycine max (L.) Merrill, in different containers in Southern Nigeria. Global J. Pure and Appl. Sci., 41: 26-31.

Sajo, A.A. and Tame, V.T. 2012. Effects of Storage Materials and Environmental Conditions on Time of Germination of Soybean (Glycine max (L.) Merril) Seed in Yola, Nigeria. Acta Horticulture Number 1012: 71-76.

Shelar, V.R., Shaikh R.S., Nikam A.S. 2008. Soybean seed quality during storage: A Review. Agric. Rev., 29(2): 125-131.

Sushma, D.M. 2003. Effect of seed treatment and containers on seed storability of garden pea (Pisum sativum L.. M.Sc. Agri.) Thesis, U.A.S. Dharward.

Tame, V.T. and Elam, Y. 2015. Effects of Storage Materials and Environmental Conditions on Germination Percentage of Soybean (Glycine Max (L.) Merril) Seeds in Yola Nigeria. Inter. J. Agril. Sci. Natural Res., 2(4): 90-94.

Tame, V.T. 2011. Viability and Vigour of Soybean Seed (Glycine max (L.) Merril. LAP Lambert Academic Publishing GmbH \& Co. KG, Germany.

Tame, V.T. and Ayuba, K. 2009. Water absorption index of soybean seed (Glycine $\max$ (L.) Merril) stored in different materials and environmental conditions in Yola, Nigeria. Nigerian J. Trop. Agric., 11: 72-82.

Tame, V.T., Gungula, D.T. and Sajo, A.A. 2013. Speed of Emergence of Soybean (Glycine max (L.) Merril) Seeds Stored in Different Materials and Environmental Conditions in Yola Nigeria. Int. J. Adv. Res., 1(3): 86-89. 
Tatipata, A. 2009. Effect of seed moisture content, packaging and storage period on mitochondria inner membrane of soybean seed. J. Agri. Technol., 5(1): 51-64.

Tekrony, D.M. and D.B. Egli. 1999. Seedbed Conditions and Prediction of Field
Emergence of Soybean Seed. Seed Sci. and Tech., 21: 127-137

Walters, C., Hill, L.M. and Wheeler, L.J. 2005. Drying while dry: kinetics and mechanisms of deterioration in descated organism. Integrated Comp, Biol., 45: 751-758.

\section{How to cite this article:}

Nataraj, K., and Jayaramegowda. 2017. Effects of Packaging Materials and Seed Treatments Chemicals on Seed Quality Attribute in Vegetable Soybean during Storage. Int.J.Curr.Microbiol.App.Sci. 6(5): 1609-1614. doi: https://doi.org/10.20546/ijcmas.2017.605.175 